\title{
AGRO-INDUSTRIAL RESIDUES AND STARCH FOR GROWTH AND CO-PRODUCTION OF POLYHYDROXYALKANOATE COPOLYMER AND $\alpha$-AMYLASE BY BACILLUS SP. CFR-67
}

\author{
Shamala T. R.*; Vijayendra S.V.N.; Joshi G.J.
}

Department of Food Microbiology, Central Food Technological Research Institute, (A constituent laboratory of Council of Scientific and Industrial Research, New Delhi, India), Mysore- 570 020, India.

Submitted: January 17, 2011; Returned to authors for corrections: April 05, 2011; Approved: June 07, 2012.

\begin{abstract}
Polyhydroxyalkanoates (PHA) and $\alpha$-amylase ( $\alpha$-1,4 glucan-4-glucanohydrolase, E.C. 3.2.1.1) were coproduced by Bacillus sp. CFR-67 using unhydrolysed corn starch as a substrate. Bacterial growth and polymer production were enhanced with the supplementation of hydrolysates of wheat bran (WBH) or rice bran $(\mathrm{RBH})$ individually or in combination (5-20 $\mathrm{g} \mathrm{L}^{-1}$, based on weight of soluble substrates-SS). In batch cultivation, a mixture of WBH and RBH $\left(1: 1,10 \mathrm{~g} \mathrm{~L}^{-1}\right.$ of SS) along with ammonium acetate $\left(1.75 \mathrm{~g} \mathrm{~L}^{-1}\right)$ and corn starch $\left(30 \mathrm{~g} \mathrm{~L}^{-1}\right)$ produced maximum quantity of biomass $\left(10 \mathrm{~g} \mathrm{~L}^{-1}\right)$ and PHA $\left(5.9 \mathrm{~g} \mathrm{~L}^{-1}\right)$. The polymer thus produced was a copolymer of polyhydroxybutyrate-co-hydroxyvalerate of 95:5 to $90: 10 \mathrm{~mol} \%$. Presence of WBH and corn starch (10-50 $\left.\mathrm{g} \mathrm{L}^{-1}\right)$ in the medium enhanced fermentative yield of $\alpha$-amylase $\left(2-40 \mathrm{U} \mathrm{mL}^{-1} \mathrm{~min}^{-1}\right)$. The enzyme was active in a wide range of $\mathrm{pH}(4-9)$ and temperature $\left(40-60^{\circ} \mathrm{C}\right)$. This is the first report on simultaneous production of copolymer of bacterial PHA and $\alpha$-amylase from unhydrolysed corn starch and agro-industrial residues as substrates.
\end{abstract}

Key words: $\alpha$-amylase, Bacillus sp., Corn starch, Polyhydroxyalkanoate, Rice bran hydrolysate, Wheat bran hydrolysate.

\section{INTRODUCTION}

Polyhydroxyalkanoate (PHA), an intracellular carbon reserve of the bacterial cell has gained worldwide attention as biodegradable thermoplastic (16). Various bacteria commonly produce polyhydroxybutyrate (PHB), however, this polymer is crystalline and brittle. The copolymer of poly(hydroxybutyrateco-hydroxyvalerate) $[\mathrm{P}(\mathrm{HB}-\mathrm{co}-\mathrm{HV})]$ and other copolymers have better mechanical properties and hence are useful for various applications (1). Copolymer production depends on the carbon substrate provided for fermentation and the type of PHA-synthesis genes present in the bacterium. For sustained commercialization it is essential to explore economic substrates for bacterial growth and copolymer production (1). With this in view, a few agro-industrial residues such as hydrolysed wheat bran, extruded rice bran, oil seed cakes and potato starch are employed as carbon substrates for the synthesis of bacterial PHA $(13,24,37)$. 
Application of agro-industrial residues for bioprocesses, such as enzyme production is known to yield higher titers of the product. Invariably enzymes such as $\alpha$-amylase, $\beta$-amylase, glucoamylase, proteases and lipases of microbial origin are produced using wheat bran, rice barn, oil seed cakes and other agro-residues as substrates in submerged or solid state fermentations and these enzymes have several applications in different industries $(5,26,33,34)$. The $\alpha$-amylase produced from bacteria has attained commercial significance and finds wide application in food, paper and textile industries. Most abundantly used bacterial amylase is derived from Bacillus spp. Combinations of groundnut oil seed cake and wheat bran have proved to be good substrates for the fermentative production of $\alpha$-amylase by Bacillus amyloliquefaciens (7).

Various Bacillus spp. are known to produce PHA $(6,18$, $31,38)$ and they also produce $\alpha$-amylase extracellularly, which has several commercial applications $(2,12)$. Present study is the first attempt to produce $\alpha$-amylase and PHA-copolymer simultaneously by Bacillus sp. using unhydrolysed corn starch as a carbon substrate and enzyme hydrolysed wheat bran and rice bran as enhancers of growth and metabolite production.

\section{MATERIALS AND METHODS}

\section{Microorganism}

The bacterial culture was isolated from soil sample, subjected to basic tests for preliminary identification (29), identified as Bacillus sp. and was assigned the strain number CFR-67. The bacterium showed negative result for haemolysis test, hence appeared to be a non-pathogenic strain. The purified culture was streaked on nutrient agar (Himedia Laboratories, Mumbai, India) slants, incubated at $30^{\circ} \mathrm{C}$ for $18 \mathrm{~h}$ and then refrigerated at $4^{\circ} \mathrm{C}$ for further use.

\section{Inoculum}

Bacterial cells from $18 \mathrm{~h}$ old slant culture were transferred into $10 \mathrm{~mL}$ of sterile nutrient broth and incubated at $200 \mathrm{rev}$ $\min ^{-1}$ at $30^{\circ} \mathrm{C}$ for $18 \mathrm{~h}$. This inoculum, which contained $2 \times 10^{3}$
CFU mL $\mathrm{mL}^{-1}$, was used in the experiments at $10 \%(\mathrm{v} / \mathrm{v})$ level.

\section{Hydrolysis of wheat bran and rice bran}

Hydrolysed wheat bran $(\mathrm{WBH})$ and rice bran $(\mathrm{RBH})$ were used as media supplements in this study. Wheat (Triticum sp.) bran and rice (Oryza sativa) bran were procured from local market. Wheat bran contained (g-\%): moisture, 12.8; protein, 10; ash, 6; fiber, 9; fat, 3.8 and carbohydrates, 34. Components in rice bran were (g-\%): moisture, 10; protein, 16; oil, 13; ash, 14; fiber, 14 and carbohydrates 27 . The oil contained in rice bran was composed of (\%): lauric acid, 0.4; palmitic acid, 21; oleic acid, 42; linoleic acid, 31; palmitoleic acid, 0.3; myristic acid, 0.4; stearic acid, 3; linolenic acid, 1 and arachidonic acid, 0.6 (11). Wheat bran and rice bran (100 g) were suspended in distilled water (1L), individually, and the starch present was liquefied by $\alpha$-amylase (5000 units; Anilozyme, Anil starch industries, Ahamedabad, Gujrat, India) at $80^{\circ} \mathrm{C}$ for $30 \mathrm{~min}$ and cooled. Protein was hydrolysed by Alcalase 2L (5 IU; Novozyme, Denmark) and lipids by lipase from Aspergillus niger (300 U, Zeus Biotech, Mysore, India) at $\mathrm{pH} 7,40^{\circ} \mathrm{C}$ for 1 $\mathrm{h}$ and finally the liquefied starch was saccharified using amyloglucosidase (5000 units; Anilozyme, Anil starch industries, Ahamedabad, Gujrat, India) at $50^{\circ} \mathrm{C}, \mathrm{pH} 5.5$ for $4 \mathrm{~h}$ and cooled. The hydrolysates were filtered and the supernatants were centrifuged at $8000 \mathrm{rev} \mathrm{min}^{-1}$ for $15 \mathrm{~min}$. Volume of the clarified supernatants was made up to one liter and stored in a freezer for further use. Total reducing sugar (23), amino acids (30) and free fatty acids (19) were estimated in the hydrolysates. The enzymes used for hydrolysis were heat inactivated during media preparation.

\section{Shake flask cultivation}

The basal production medium for batch culture contained (g L $\left.{ }^{-1}\right): \mathrm{Na}_{2} \mathrm{HPO}_{4} .2 \mathrm{H}_{2} \mathrm{O}-2.2 ; \mathrm{KH}_{2} \mathrm{PO}_{4}-1.5 ; \mathrm{MgSO}_{4} .7 \mathrm{H}_{2} \mathrm{O}-0.2$; ammonium acetate -1.75 and corn starch of different concentrations as indicated below, as a carbon source. Reducing sugar concentration in the hydrolysates was also considered to maintain C-concentration between $10-50 \mathrm{~g} \mathrm{~L}^{-1}$ in 
the following experiments. Preliminary experiments were conducted using conventional method to find out the effect of various parameters on the production of biomass, PHA and enzyme, based on which further experiments were carried out as follows: a) The effect of $\mathrm{WBH}$ or $\mathrm{RBH}$ individually and in combination at $125-500 \mathrm{ml} \mathrm{L}^{-1}\left(5-20 \mathrm{~g} \mathrm{~L}^{-1}\right.$ of soluble substrateSS) level and $30 \mathrm{~g} \mathrm{~L}^{-1}$ of corn starch; basal medium without the hydrolysates $\left(30 \mathrm{~g} \mathrm{~L}^{-1}\right.$ of corn starch or glucose served as a control), b) Corn starch concentration was varied between 10$50 \mathrm{~g} \mathrm{~L}^{-1}$ in $1: 1$ of $\mathrm{WBH}$ and $\mathrm{RBH}\left(5 \mathrm{~g} \mathrm{~L}^{-1}\right.$ of SS each from WBH and RBH) containing medium; c) Medium without ammonium acetate and with $\mathrm{WBH}, \mathrm{RBH}$ and their mixtures (5-20 $\mathrm{g} \mathrm{L}^{-1}$ of SS) and corn starch $\left(30 \mathrm{~g} \mathrm{~L}^{-1}\right)$ was used to find out the effect of complex nitrogen source on extracellular $\alpha$ amylase production; d) Production of $\alpha$-amylase in different concentrations of corn starch was worked out by using 10-50 g $\mathrm{L}^{-1}$ of corn starch in medium without ammonium acetate and with $125 \mathrm{ml} \mathrm{L}^{-1}$ of WBH (SS, $5 \mathrm{~g} \mathrm{~L}^{-1}$ ). All the experiments were carried out in shake flasks by using sterile production medium $(100 \mathrm{~mL})$ taken in $250 \mathrm{~mL}$ capacity Erlenmeyer flasks. Medium was inoculated with $10 \%(\mathrm{v} / \mathrm{v})$ of inoculum and the flasks were incubated on a shaker at $200 \mathrm{rev} \min ^{-1}$ for $72 \mathrm{~h}$ at $30^{\circ} \mathrm{C}$. Experiments were carried out in triplicate.

\section{Biomass estimation}

Fermented broth was centrifuged at $8000 \mathrm{rev} \mathrm{min}^{-1}$ for 15 min to sediment the cells. Residual starch, if present, was removed by treatment with $\alpha$-amylase $\left(70^{\circ} \mathrm{C}\right.$ for $\left.30 \mathrm{~min}\right)$ and amyloglucosidase $\left(50^{\circ} \mathrm{C}\right.$ for $\left.3 \mathrm{~h}\right)$, washed with distilled water, dried in the oven at $70^{\circ} \mathrm{C}$ till a constant dry weight of the biomass was obtained. Biomass weight included intracellular PHA.

\section{PHA estimation}

The polymer was extracted from the cells, dried at $70^{\circ} \mathrm{C}$ to a constant weight and estimated gravimetrically (16). For GC and ${ }^{1} \mathrm{H}$ NMR analysis, PHA was extracted from lyophilized cells using chloroform for $2-4 \mathrm{~h}$ at $45^{\circ} \mathrm{C}$ and the clear filtrate was homogenized with 2 volumes of hexane to precipitate the polymer. The polymer was dried at $50^{\circ} \mathrm{C}$ to a constant weight. Isolated polymer was subjected to methanolysis by heating at $100^{\circ} \mathrm{C}$ for $140 \mathrm{~min}$ in the presence of sulfuric acid, methanol and chloroform to obtain methyl ester of PHA and the polymer was quantified by GC $(3,17,31)$. PHB and P(HB-co-HV) from Sigma Aldrich, USA, were used as standards. Benzoic acid (Sigma, USA) was used as an internal standard.

\section{Nuclear Magnetic Resonance (NMR) spectroscopy}

Pure PHA (5 mg mL $\left.{ }^{-1}\right)$ was dissolved in $1 \mathrm{~mL}$ of $\mathrm{CDCl}_{3}$ (deuterated chloroform) and subjected to ${ }^{1} \mathrm{H}$ NMR at $500 \mathrm{MHz}$ on an AMX 500 (Bruker 500) spectrophotometer $(18,31) .{ }^{1} \mathrm{H}$ spectra were obtained at $27^{\circ} \mathrm{C}$ and $45^{\circ}$ pulse angle. PHB and P(HB-co-HV) procured from Sigma Aldrich, USA, were used as standards.

\section{$\alpha$-Amylase assay}

Supernatant obtained after separation of biomass was used for $\alpha$-amylase assay by spectroscopic method (21). For the assay, reduction in blue colour intensity resulting from enzyme hydrolysis of starch was measured. The assay was carried out at $60^{\circ} \mathrm{C}$ for $10 \mathrm{~min}$. Enzyme unit (DU) activity was defined as mg of starch hydrolysed per minute under the assay conditions (U mL ${ }^{-1} \min ^{-1}$ ).

\section{Effect of temperature and $\mathrm{pH}$ on $\alpha$-amylase activity}

Activity profile of the enzyme present in the culture filtrate was determined by the method detailed as above, at different temperatures and $\mathrm{pH}$. Enzyme used for experiment had an activity of $87 \mathrm{U} \mathrm{mL}^{-1}\left(8.7 \mathrm{U} \mathrm{mL}^{-1} \mathrm{~min}^{-1}\right)$ at $\mathrm{pH} 5$ and at $60^{\circ} \mathrm{C}$. For temperature profile, assay was carried out at 30, 40, $50,60,70$ and $80^{\circ} \mathrm{C}$ at $\mathrm{pH} 5$ (acetate buffer, $0.1 \mathrm{M}$ ) for $10 \mathrm{~min}$. To determine the suitable $\mathrm{pH}$ range, $\mathrm{pH}$ of the enzyme assay buffer $(0.1 \mathrm{M})$ was varied between 3-6 (acetate buffer), 7-8 (phosphate buffer) and 9-10 (glycine buffer) at $60^{\circ} \mathrm{C}$ for 10 $\min$. 


\section{Statistical analysis}

Statistical analysis of the results obtained for the shake flask experiments was carried out using computer based Microsoft excel programme with nonbiased or n-1 method.

\section{RESULTS AND DISCUSSION}

Cultivation of Bacillus sp. on unhydrolysed starch for PHA production

The isolated strain of Bacillus sp. CFR-67 grew optimally and produced more biomass $\left(2.5 \mathrm{~g} \mathrm{~L}^{-1}\right)$ and PHA $\left(1.5 \mathrm{~g} \mathrm{~L}^{-1}\right)$ on corn starch, as a carbon source, compared to glucose $(2.0$ and $1.0 \mathrm{~g}$ $\mathrm{L}^{-1}$, respectively, Table 1). Yields obtained were comparable to reported values by Valappil et al. (36) who have shown biomass yield of $2.1 \mathrm{~g} \mathrm{~L}^{-1}$ with $38 \%$ PHA with glucose as a carbon source in Bacillus cereus. For enhancement of yields, nutrient rich WBH and $\mathrm{RBH}$ were used as media supplements. WBH prepared in this study contained $\left(\mathrm{g} \mathrm{L}^{-1}\right)$ : 40 of SS with 28 of reducing sugars, 6 of free amino acids and 0.6 of free fatty acids and the corresponding values for RBH were 21, 8 and $6 \mathrm{~g} \mathrm{~L}^{-1}$. The degree of hydrolysis of the substrates was: starch, $85 \%$; protein, $50-60 \%$ and fat about $45 \%$. As shown in Table 1, WBH or RBH, either individually or in combination gave significant increase in the biomass and PHA production, but the highest yields of biomass $\left(10 \mathrm{~g} \mathrm{~L}^{-1}\right)$ and PHA $\left(5.9 \mathrm{~g} \mathrm{~L}^{-1}\right)$ were obtained in medium containing WBH + RBH $(1: 1$ ratio, equivalent to $5 \mathrm{~g} \mathrm{~L}^{-1} \mathrm{SS}$ from each of the substrate), $1.75 \mathrm{~g} \mathrm{~L}^{-}$ ${ }^{1}$ of ammonium acetate and $30 \mathrm{~g} \mathrm{~L}^{-1}$ of corn starch. PHAs are produced as carbon energy of the cells under nutrient depletion conditions such as nitrogen, phosphate, magnesium, oxygen etc. in the presence of excess carbon source (16). However, increased addition of corn starch as a carbon source beyond certain limit supported more growth and considerable changes in polymer yields were not observed (Figure 1).

Table 1. Production of biomass and polyhydroxyalkanoate (PHA) by Bacillus sp. CFR-67 in media containing different concentrations of wheat bran and rice bran hydrolysates.

\begin{tabular}{|c|c|c|c|c|c|c|}
\hline Medium & $\mathrm{SS}^{\mathrm{c}}\left(\mathrm{g} \mathrm{L}^{-1}\right)$ & Biomass $^{\mathrm{d}}\left(\mathrm{g} \mathrm{L}^{-1}\right)$ & PHA $\left(\mathrm{g} \mathrm{L}^{-1}\right)$ & PHA (\% of biomass) & PHB:PHV & $\mathrm{mol} \%$ \\
\hline \multirow{3}{*}{$\mathrm{WBH}^{\mathrm{a}}$} & 5.0 & $6.1 \pm 0.3$ & $2.3 \pm 0.5$ & $38 \pm 6$ & NA & \\
\hline & 10.0 & $7.1 \pm 0.5$ & $2.6 \pm 0.2$ & $34 \pm 3$ & $99: 1$ & \\
\hline & 20.0 & $8.8 \pm 0.2$ & $3.0 \pm 0.2$ & $34 \pm 1$ & NA & \\
\hline \multirow{3}{*}{$\mathrm{RBH}^{\mathrm{b}}$} & 5.0 & $4.7 \pm 0.3$ & $1.7 \pm 0.3$ & $36 \pm 4$ & NA & \\
\hline & 10.0 & $7.2 \pm 0.3$ & $2.9 \pm 0.2$ & $40 \pm 1$ & $90: 10$ & \\
\hline & 20.0 & $7.3 \pm 0.5$ & $2.3 \pm 0.5$ & $32 \pm 4$ & NA & \\
\hline \multirow{3}{*}{$\mathrm{RBH}+\mathrm{WBH}$} & 5.0 & $5.1 \pm 0.4$ & $1.8 \pm 0.2$ & $35 \pm 1$ & NA & \\
\hline & 10.0 & $10.0 \pm 0.2$ & $5.9 \pm 0.1$ & $59 \pm 2$ & $95: 5$ & \\
\hline & 20.0 & $8.0 \pm 0.2$ & $2.3 \pm 0.5$ & $29 \pm 6$ & NA & \\
\hline \multirow{2}{*}{\multicolumn{2}{|c|}{$\begin{array}{l}\text { Control }\left(30 \mathrm{~g} \mathrm{~L}^{-1} \text { of glucose }\right) \\
\text { Control }\left(30 \mathrm{~g} \mathrm{~L}^{-1} \text { of corn starch) }\right.\end{array}$}} & $2.0 \pm 0.5$ & $1.0 \pm 0.3$ & $50 \pm 2$ & $100: 0$ & \\
\hline & & $2.5 \pm 0.4$ & $1.5 \pm 0.3$ & $60 \pm 2$ & 100:0 & \\
\hline
\end{tabular}

${ }^{a}$ Wheat bran hydrolysate $(\mathrm{WBH}){ }^{\mathrm{b}}$ Rice bran hydrolysate $(\mathrm{RBH})$, were used in liquid form.

${ }^{c}$ Amount of equivalent soluble substrate (SS) from WBH/RBH used in the medium is shown as $\mathrm{g} \mathrm{L}^{-1}$; medium also contained ammonium acetate (1.75 $\mathrm{g} \mathrm{L}^{-1}$ ) and corn starch (Total C-source, $30 \mathrm{~g} \mathrm{~L}^{-1}$ ); cultivation was carried out at $30^{\circ} \mathrm{C}, 200 \mathrm{rev} \mathrm{min}^{-1}$ for $72 \mathrm{~h}$; ${ }^{\mathrm{d}}$ Biomass with PHA; NA: Sample not analysed.

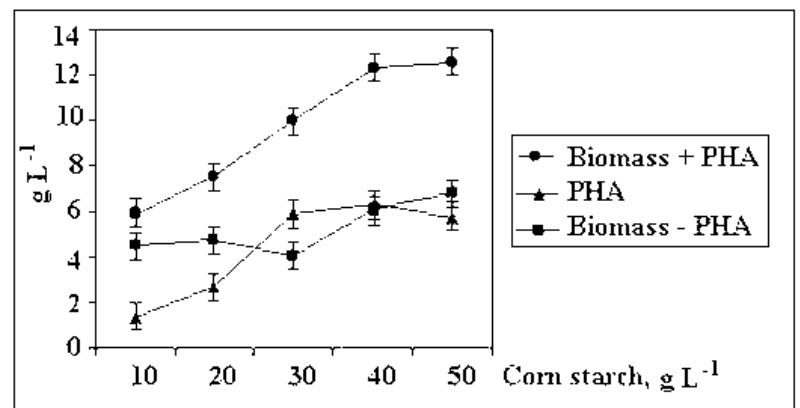

Figure 1. Growth and PHA production by Bacillus sp. CFR-67 in the medium containing rice bran hydrolysate + wheat bran hydrolysate (1:1; soluble substrate from each is $\left.5 \mathrm{~g} \mathrm{~L}^{-1}\right)$, ammonium acetate $\left(1.75 \mathrm{~g} \mathrm{~L}^{-1}\right)$ and various concentrations of unhydrolysed corn starch. Cultivation details are as indicated in Table 1. 
Several genera of bacteria produce polyhydroxybutyrate (PHB), however, PHA copolymers are known to be commercially important for various applications compared to homopolymers (1). Bacillus spp. are reported to synthesize various PHA copolymers containing 3-hydroxybutyrate, 3hydroxyvalerate, 4-hydroxybutyrate, 6-hydroxyhexanoate and hydroxyoctanoate monomeric units from structurally unrelated carbon sources namely glucose, fructose, sucrose, gluconate, certain amino acids, 4-hydroxybutyric acid, $\alpha$ - $\omega$-alkanediols, caproate, $\varepsilon$-caprolactone etc $(1,4,6,18,36)$. In the present study, Bacillus sp. synthesized PHA copolymer of PHB:PHV of 90:10 mol\%. The ${ }^{1} \mathrm{H}$ NMR spectrum of the polymer indicated signals characteristic for PHB: a doublet at $1.29 \mathrm{ppm}$, which is attributed to the methyl group, a doublet of quadruplet at $2.5 \mathrm{ppm}$ for methylene group and a multiplet at $5.28 \mathrm{ppm}$, which is characteristic of methyne group. A triplet at $0.9 \mathrm{ppm}$ and a methylene resonance at 1.59 and methyne resonance at
5.25 indicated the presence of valerate (Figure 2). It is reported that Ralstonia eutropha produced $\mathrm{P}(\mathrm{HB}-\mathrm{co}-\mathrm{HV})$ copolymer when propionic acid, valeric acid or other fatty acids with an odd number of carbon atom was present in the cultivation medium (22). Bacteria can produce PHA on several cheaper raw materials such as whey, waste water from olive mills, molasses, corn steep liquor, starchy waste water, palm oil mill effluent, mahua flower extract, sugarcane liquor, wheat hydrolysate etc. $(1,8,9,14,20,22,25,28,38)$. Van-Thuoc et al. (37) have shown that Halomonas boliviensis utilizes wheat bran hydrolysate as a carbon source for PHB production. In the present study, WBH and RBH that contained amino acids, fatty acids and carbohydrates were used along with unhydrolysed corn starch as nutrients for growth and copolymer production. Utilization of native carbon substrate has better advantage for commercial production of the polymer in reducing its cost of production.

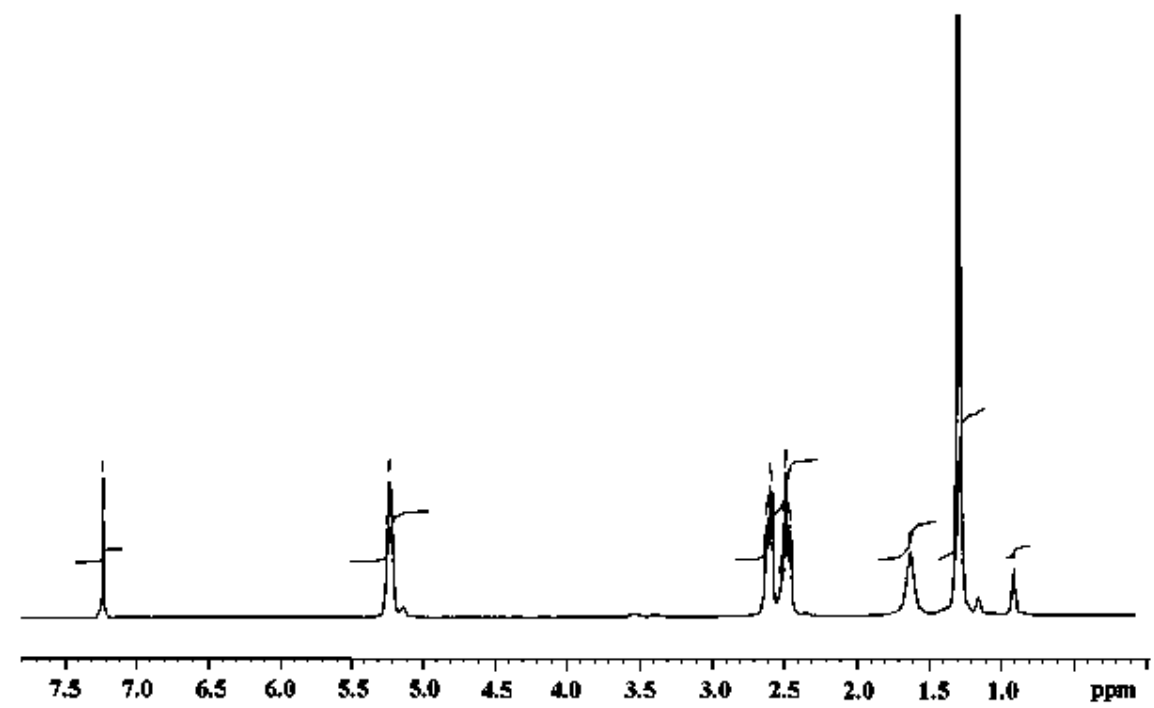

Figure 2. ${ }^{1} \mathrm{H}$ NMR spectrum of PHA isolated from the cells of Bacillus sp. CFR-67.

\section{Co-production of PHA and $\alpha$-amylase by Bacillus sp.}

Wheat bran is widely recognized as an optimal solid substrate rich in nutrients for fermentative production of enzymes such as $\alpha$-amylase (7). WBH and RBH used in the current study contained free amino acids or small peptides, which formed an excellent source of nitrogen for bacterial growth and cell protein production. In $\mathrm{WBH} / \mathrm{RBH}$ medium containing ammonium acetate as additional nitrogen source 
(Table 1), low amylase activity was observed, which appeared sufficient for continuous hydrolysis of starch present in the medium leading to high biomass and PHA production.

Fermentation experiments were repeated in the absence of ammonium acetate and with $\mathrm{WBH}$ or/and $\mathrm{RBH}$ as nitrogen source(s). Enhanced supplementation of complex nitrogen source in the form of $\mathrm{WBH} / \mathrm{RBH}$ for submerged fermentation also adversely affected the growth, production of PHA and $\alpha$-amylase
(Figure 3). Highest titer of $\alpha$-amylase (7.5 $\mathrm{U} \mathrm{mL}^{-1} \mathrm{~min}^{-1}$ ) was observed in low concentration of WBH (SS, $5 \mathrm{~g} \mathrm{~L}^{-1}$ ) and the enzyme activity decreased with increase in concentration of the hydrolysate (Figure 3). However, maximum concentration of PHA of about $2 \mathrm{~g} \mathrm{~L}^{-1}$ was obtained in $\mathrm{WBH} / \mathrm{RBH}$ and their mixtures (SS, $10 \mathrm{~g} \mathrm{~L}^{-1}$ ). This finding on lowering of enzyme yield under excess nitrogen supplementation is in agreement with earlier reported work $(10,15,27,35)$.
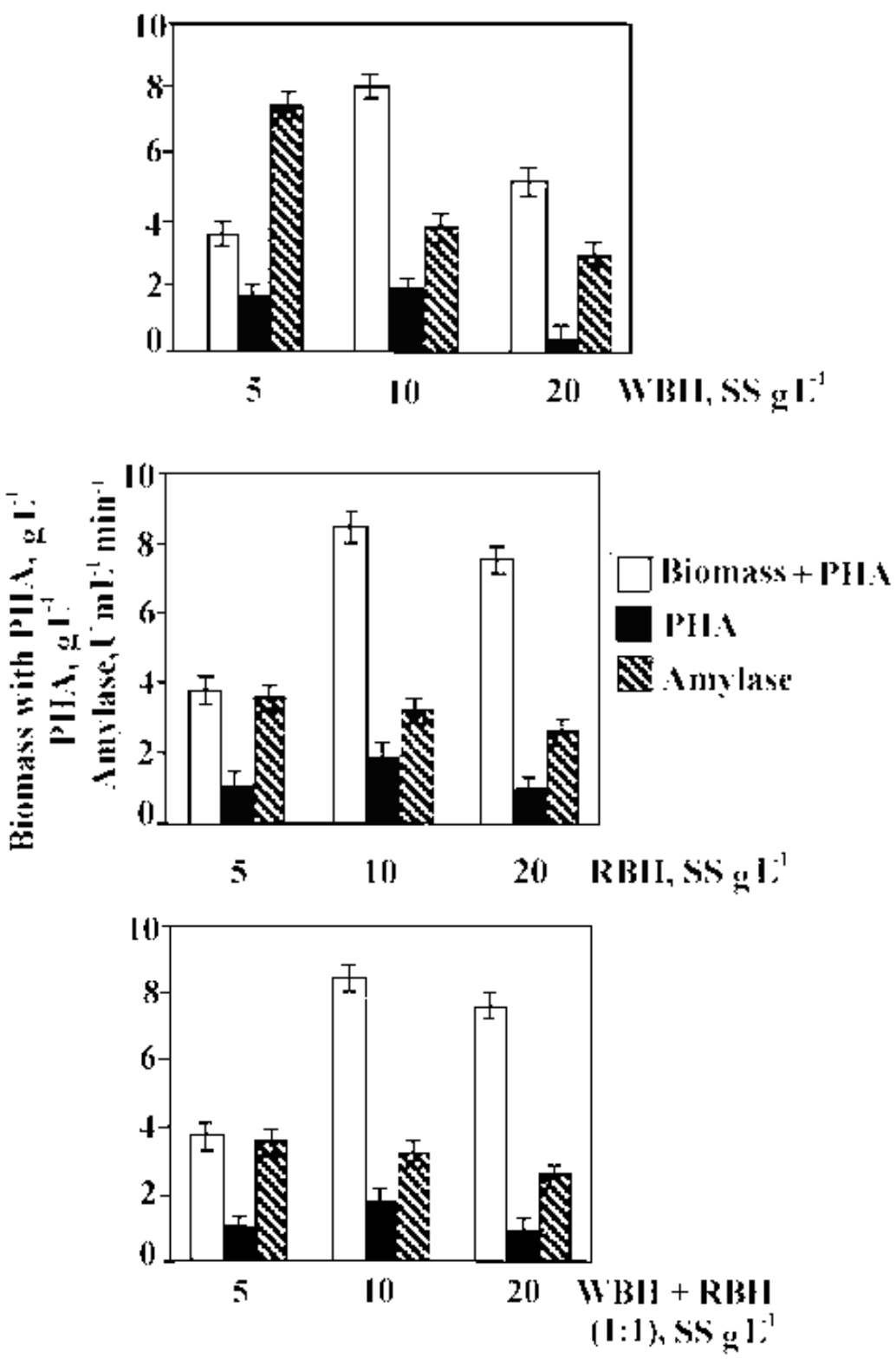

Figure 3. Effect of soluble substrates $\left(\mathrm{SS}, \mathrm{g} \mathrm{L}^{-1}\right)$ from Wheat bran hydrolysate (WBH), Rice bran hydrolysate (RBH) and their mixtures on the production of PHA and $\alpha$-amylase by Bacillus sp. CFR-67 in the absence of additional supplementation of nitrogen for growth. Corn starch was used at $30 \mathrm{~g} \mathrm{~L}^{-1}$, other parameters are as indicated in Table 1. 
In the presence of $\mathrm{WBH}$ as $\mathrm{N}$-source (SS, $5 \mathrm{~g} \mathrm{~L}^{-1}$ ) and with different concentrations of corn starch of 10-50 $\mathrm{g} \mathrm{L}^{-1}$, maximum yield of biomass, PHA and $\alpha$-amylase of $5 \mathrm{~g} \mathrm{~L}^{-1}, 2.5 \mathrm{~g} \mathrm{~L}^{-1}$ and 12 $\mathrm{U} \mathrm{mL} \mathrm{min}^{-1}$, respectively, were obtained for $30 \mathrm{~g} \mathrm{~L}^{-1}$ of carbon source. Activity of $\alpha$-amylase enhanced with increased concentration of corn starch and reached a maximum of $40 \mathrm{U} \mathrm{mL}^{-1}$ $\min ^{-1}(120 \mathrm{mg} \%$ soluble protein in broth; specific activity of $20 \mathrm{U}$ $\mathrm{mg}^{-1}$ protein) at $50 \mathrm{gL}^{-1}$ of starch concentration (Figure 4).
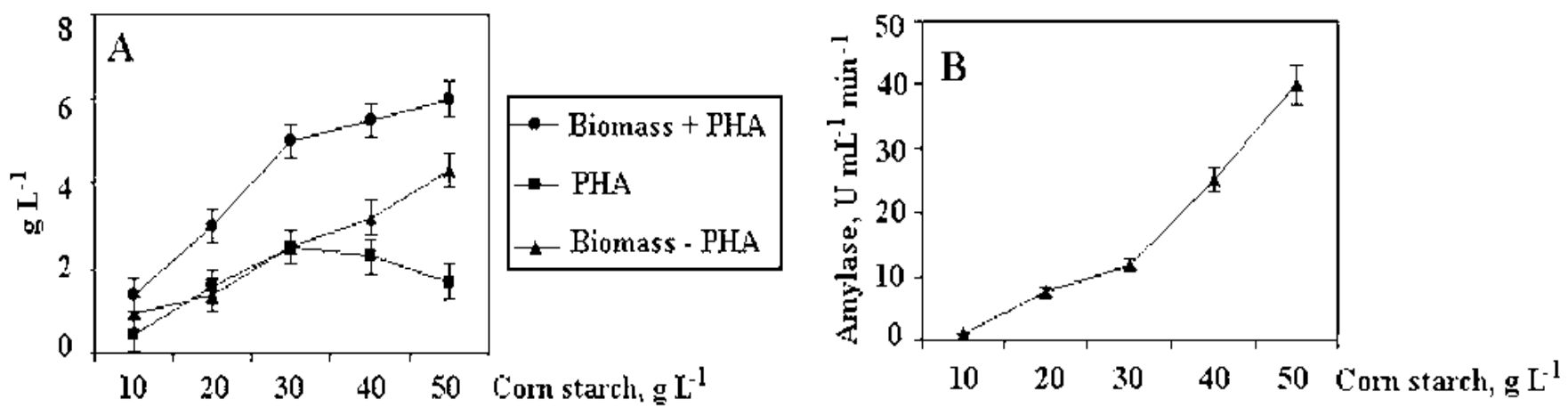

Figure 4. Growth, PHA (A) and $\propto$-amylase activity (B) produced by Bacillus sp. CFR-67 in Wheat bran hydrolysate medium (soluble substrate, $5 \mathrm{~g} \mathrm{~L}^{-1}$ ), lacking ammonium acetate and supplemented with various concentrations of unhydrolysed corn starch. Cultivation details as given in Table 1 .

\section{Properties of $\alpha$-amylase produced by Bacillus sp.}

Liquefaction of starch is generally carried out at temperatures of $60-90^{\circ} \mathrm{C}$, hence thermostable $\alpha$-amylase is of great significance (32). In this study, $\alpha$-amylase produced by Bacillus sp. CFR-67 showed retention of considerable enzyme activities from lower to higher temperature and at different $\mathrm{pH}$ (40-60 ${ }^{\circ} \mathrm{C}$; $\mathrm{pH} 4-9$; Figure 5). At $80^{\circ} \mathrm{C}, 60 \%$ loss in enzyme activity was noticed, when compared to its activity at $60^{\circ} \mathrm{C}(8.7$ $\mathrm{U} \mathrm{mL} \mathrm{min}^{-1}$, Figure 5A). Optimum activity was observed at $\mathrm{pH} 8$ and $60^{\circ} \mathrm{C}\left(10 \mathrm{U} \mathrm{mL}^{-1} \mathrm{~min}^{-1}\right.$, Figure 5B). According to Soni et al. (32) $\alpha$-amylase produced by Bacillus sp. possessed 88,85 and $44 \%$ of activity at 60,70 and $80^{\circ} \mathrm{C}$, respectively. It is reported that maximum enzyme activity is found at $\mathrm{pH} 5$ and the use of alkaline buffer $(\mathrm{pH}, 9)$ results in a sharp decline in the enzyme activity (10). Enzyme produced by Bacillus sp. in our study had desirable characteristics and can be used efficiently for starch liquefaction.

Bacillus spp. are known to produce $\alpha$-amylase in solid substrate fermentation with agro-industrial by products such as wheat bran, coconut oil cake as substrates $(2,10)$. In the present study, the enzyme was coproduced extracellularly in submerged fermentation along with intracellular accumulation of polyhydroxyalkanoate and both the products are of commercial interest.

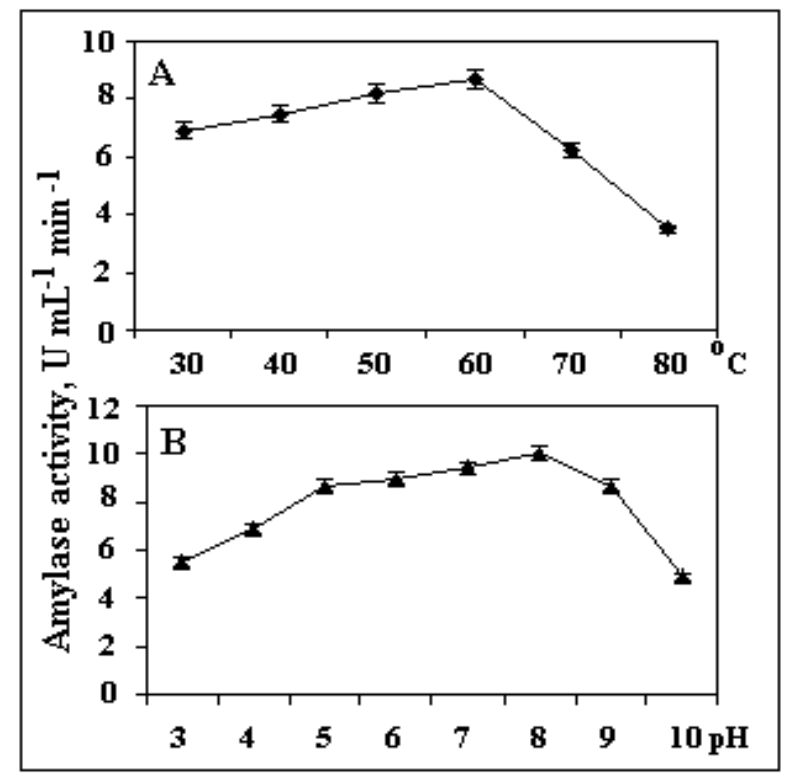

Figure 5. Effect of temperature (A) and $\mathrm{pH}$ (B) on $\propto$-amylase activity produced by Bacillus sp. CFR-67. 


\section{CONCLUSION}

The results obtained in the present study indicated the potentiality of Bacillus sp. CFR-67 to co-produce PHA and commercially important $\alpha$-amylase from agro-industrial residues such as wheat bran and rice bran hydrolysates as growth supplements and native corn starch as main carbon source. It produced maximum quantity of biomass $\left(10 \mathrm{~g} \mathrm{~L}^{-1}\right)$ and PHA (5.9 $\mathrm{g} \mathrm{L}^{-1}$ ) copolymer of polyhydroxybutyrate-cohydroxyvalerate of $95: 5$ to $90: 10 \mathrm{~mol} \%$, in a medium containing a mixture of $\mathrm{WBH}$ and $\mathrm{RBH}\left(1: 1,10 \mathrm{~g} \mathrm{~L}^{-1}\right.$ of SS) along with ammonium acetate $\left(1.75 \mathrm{~g} \mathrm{~L}^{-1}\right)$ and corn starch $(30$ $\left.\mathrm{g} \mathrm{L}^{-1}\right)$. PHA copolymer has better mechanical properties, biodegradable, has potential applications and envisaged to replace synthetic polymers. Maximum activity of $\alpha$-amylase (40 $\mathrm{U} \mathrm{mL}^{-1} \mathrm{~min}^{-1}$ ) was observed in $\mathrm{WBH}$ medium with corn starch. Furthermore, $\alpha$-amylase showed activity in a wide range of $\mathrm{pH}$ and temperature, indicating applicability of the enzyme for starch liquefaction at high temperature.

\section{ACKNOWLEDGEMENTS}

Authors thank Director, CFTRI, Mysore, for the encouragement to carry out the study.

\section{REFERENCES}

1. Anil Kumar, P.K.; Shamala, T.R.; Kshama, L.; Prakash, M.H.; Joshi, G.J.; Chandrashekar, A.; Latha Kumari, K.S.; Divyashree, M.S. (2007). Bacterial synthesis of poly(hydroxybutyrate-co-hydroxyvalerate) using 16. carbohydrate rich Mahua (Madhuca sp.) flowers. J. Appl. Microbiol.103, 204-209.

2. Baysal, Z.; Uyar, F.; Aytekin, C. (2003). Production of $\propto$-amylase by thermotolerant Bacillus subtilis in the presence of some carbon, nitrogen containing compounds and surfactants. Ann. Microbiol. 53, 323-328.

3. Brandl, H.; Gross, R.A.; Lenz, R.W.; Fuller, R.C. (1988). Pseudomonas oleovorans as a source of poly( $\beta$-hydroxyalkanoate) for potential application as biodegradable polyesters. Appl. Environ. Microbiol. 54, 1977-1982.

4. Caballero, K.P.; Karel, S.F.; Register, R.A. (1995). Biosynthesis and characterization of hydroxybutyrate-hydroxycaproate copolymers. Int. J. Biol. Macromol. 17, 86-92.

5. Carvalho, R.V.; Correa T.L.R.; Silva, J.C.M; Mansur, L.R.C.O.; Martins, M.L.L. (2008). Properties of an amylase from thermophilic Bacillus sp. Braz. J. Microbiol. 39, 102-107.

6. Chen, G.Q.; Konig, K.H.; Lafferty, R.M. (1991). Occurrence of poly $\beta$ hydroxyalkanoates in the genus Bacillus. FEMS Microbiol. Lett. 84, 173-176.

7. Dhanya, D.; Swetha, S.; Kesavan, M.N.; Ashok, P. (2006). Solid culturing of Bacillus amyloliquefaciens for alpha amylase production. Food Technol. Biotechnol. 44, 269 -274.

8. Gouda, M.K.; Swellam, A.E.; Omar, S.H. (2001). Production of PHB by a Bacillus megaterium strain using sugarcane molasses and corn steep liquor as sole carbon and nitrogen sources. Microbiol. Res. 156, 201-207.

9. Hassan, M.A.; Shirai, Y.; Inagaki, M.; Abdul Karim, M.I.; Nakanishi, K.; Hashimoto, K. (1997). Economic analysis on production of bacterial polyhydroxyalkanoates from palm oil mill effluent. J. Chem. Eng. Japan. 30, 751-755.

10. Hema, A.; Ujjval, T.; Kamlesh, P. (2006). Alpha amylase. Production by Bacillus cereus MTCC 1305 using solid-state fermentation. Food Technol. Biotechnol. 44, 241-245.

11. Hemavathy, J.; Prabhakar, J. V. (1987). Lipid composition of rice (Oryza sativa L) bran. J. Am. Oil Chem. Soc. 64, 1016-1019.

12. Hiller, P.; Wase, D.A.J.; Emery, A.N. (1996). Production of $\alpha$-amylase by Bacillus amyloliquefaciens in batch and continuous culture using a defined synthetic medium. Biotechnol. Lett. 18, 795-800.

13. Huang, T.Y.; Duan, K.J.; Huang, S.Y.; Chen, C.W. (2006). Production of polyhydroxyalkanoates from inexpensive extruded rice bran and starch by Haloferax mediterranei. J. Ind. Microbiol. Biotechnol. 33, 701706.

14. Jiang, Y.; Song, X.; Gong, L.; Li, P.; Dai, C.; Shao, W. (2008). High poly( $\beta$-hydroxybutyrate) production by Pseudomonas fluorescens A2a5 from inexpensive substrates. Enzyme Microb. Technol. 42, 167-172.

15. Kaur, P.; Grewal, H.S.; Kocher, G.S. (2003). Production of $\alpha$-amylase by Aspergillus niger using wheat bran in submerged and solid state fermentations. Indian J. Microbiol. 43, 143-145.

Kshama, L.; Rastogi, N.K.; Shamala, T.R. (2004). Simultaneous and comparative assessment of parent and mutant strain of Rhizobium meliloti for nutrient limitation and enhanced polyhydroxyalkanoate (PHA) production using optimization studies. Process Biochem. 39, 1977-1983.

17. Kshama, L.; Shamala, T.R. (2003). Enhanced biosynthesis of polyhydroxyalkanoates in a mutant strain of Rhizobium meliloti. Biotechnol. Lett. 25, 115-119.

18. Labuzek, S.; Radecka, I. (2001). Biosynthesis of PHB tercopolymer by Bacillus cereus UW 85. J. Appl. Microbiol. 90, 353-357.

19. Lalman, J.A.; Bagley, D.M. (2004). Extracting long-chain fatty acids 
from fermentation medium. J. American Oil Chemists Society. 81, 105110.

20. Lapointe, R.; Lambert, A.; Savard, L. (2002). Process for production of biopolymer. Patent No. WO 0222841.

21. Manning, G.B.; Campbell, L.L. (1961). Thermostable $\alpha$-amylase of Bacillus stearothermophilus. I. Crystallization and some general properties. J. Biol. Chem. 236, 2952-2957.

22. Marangoni, C.; Furigo, A.; Aragao, G.M.F. (2002). Production of poly(3-hydroxybutyrate-co-3-hydroxyvalerate) by Ralstonia eutropha in whey and inverted sugar with propionic acid feeding. Process Biochem. 38, 137-141.

23. Miller, G.L. (1959). Use of dinitrosalicylic acid reagent for determination of reducing sugar. Anal. Chem. 31, 426-428.

24. Nisha, V.R.; Sudheer Kumar, S.; Carlos, R.S.; Ashok, P. (2009). Polyhydroxy-butyrate production using agro-industrial residue as substrate by Bacillus sphaericus NCIM 5149. Braz. Arch. Biol. Technol. $52,17-23$.

25. Page, W.J. (1989). Production of poly- $\beta$-hydroxybutyrate by Azotobacter vinelandii strain UWD during growth on molasses and other complex carbon sources. Appl. Microbiol. Biotechnol. 31, 329-333.

26. Pandey, A.; Nigam, P.; Soccol, C.R.; Soccol, V.T.; Singh, D.; Mohan, R. (2000). Advances in microbial amylases. Biotechnol. Appl. Biochem. 31, 135-152.

27. Pedersen, H.; Nielsen, J. (2000). The influence of nitrogen sources on alpha amylase productivity of Aspergillus oryzae in continuous cultures. Appl. Microbiol. Biotechnol. 53, 278-281.

28. Pozo, C.; Martinez-Toledo, M.V.; Rodelas, B.; Gonzalez-Lopez, J. (2002). Effects of culture conditions on the production of polyhydroxyalkanoates by Azotobacter chroococcum $\mathrm{H} 23$ in media containing a high concentration of alpechin (wastewater from olive oil mills). J. Biotechnol. 97, 125-131.

29. Reddy, S.M.; Reddy, S.R. (1998). Microbiology-Practical Manual. Sri
Padmavathi Publications, Hyderabad, India.

30. Rosen, H. (1957). An improved method for the ninhydrin assay. Arch. Biochem. Biophys. 67, 10-15.

31. Shamala, T.R.; Chandrashekar, A.; Vijayendra, S.V.N.; Kshama, L. (2003). Identification of polyhydroxyalkanoate (PHA) producing Bacillus spp. using the polymerase chain reaction (PCR). J. Appl. Microbiol. 94, 369-374.

32. Soni, S.K.; Kaur, A.; Gupta, J.K. (2003). A solid-state fermentation based bacterial $\propto$-amylase and fungal glucoamylase system and its suitability for the hydrolysis of wheat starch. Process Biochem. 39, 185192.

33. Souza, P.M.; Magalhaes, P.O. (2010). Application of microbial $\alpha$ amylase in industry-A review. Braz. J. Microbiol. 41, 850-861.

34. Sumantha, A., Deepa, P., Sandhya, C., Szakacs, G., Soccol, C. R., Pandey A. (2006). Rice bran as a substrate for proteolytic enzyme production. Braz. Arch. Biol. Technol. 49, 843-851.

35. Teodoro, C.E.S.; Martins, M.L.L. (2000). Culture conditions for the production of thermostable amylase by Bacillus sp. Braz. J. Microbiol. 31, 298-302.

36. Valappil, S.P.; Peiris, D.; Langley, G.J.; Herniman, J.M.; Boccaccini, A.R.; Bucke, C.; Roy, I. (2007). Polyhydroxyalkanoate (PHA) biosynthesis from structurally unrelated carbon sources by a newly characterized Bacillus spp. J. Biotechnol. 127, 475-487.

37. Van-Thuoc, D.; Quillaguaman, J.; Mamo, G.; Mattiasson, B. (2008). Utilization of agricultural residues for poly(3-hydroxybutyrate) production by Halomonas boliviensis LC1. J. Appl. Microbiol. 104, 420-428.

38. Vijayendra, S.V.N.; Rastogi, N.K.; Shamala, T.R.; Anil Kumar, P.K.; Kshama, L.; Joshi, G.J. (2007). Optimization of polyhydroxybutyrate production by Bacillus sp. CFR 256 with corn steep liquor as a nitrogen source. Indian J. Microbiol. 47, 170-175. 